\title{
Faktor-faktor yang Mempengaruhi Income Smoothing dengan Tarif Pajak Efektif sebagai Variabel Mediasi Perusahaan Property dan Real Estate
}

\author{
Teddy Haryadi*, Kamaliah, dan Enni Savitri \\ Fakultas Ekonomi dan Bisnis, Universitas Riau
}

\begin{abstract}
Abstrak Penelitian ini bertujuan untuk menemukan bukti secara empiris pengaruh rasio keuangan dalam hal ini Return on Equity (ROE), Debt to Total Asset (DAR), dan Current Ratio (CR) terhadap Income smoothing dengan Tarif Pajak Efektive sebagai variable mediasi. Penelitian ini dilakukan pada 12 perusahaan property dan real estate yang terdaftar di Bursa Efek Indonesia pada tahun 2013-2017. Teknik pengambilan sampel pada penelitian ini menggunakan teknik purposive sampling dan teknik analisis data menggunakan metode Partial Least Square dengan aplikasi WarpPLS 6.o. Hasil penelitian ini menunjukkan bahwa ROE dan DAR berpengaruh positif terhadap Income smoothing selain itu CR tidak berpengaruh terhadap income smoothing. selain Penelitian ini juga menemukan Tarif Pajak Efektif dapat memediasi hubungan ROE terhadap Income Smoothing dan Tarif Pajak Efektif tidak dapat memediasi hubungan DAR dan CR terhadap Income Smoothing.
\end{abstract}

Kata Kunci: income smoothing; return on equity; debt to total asset; current ratio; tarif pajak efektif

\begin{abstract}
This research aims to find empirical evidence of the influence of financial ratio in this case Return On Equity (ROE), Debt To Total Asset (DAR), and Current Ratio (CR) to income smoothing with the effective tax rate as a mediation variable. This research was conducted on 12 property dan real estate companies listed in the Indonesian Stock Exchanges in the peroid of 2013-2017. Sampling technique in this research using purposive sampling technique and data analysis technique using Partial Least Square method using WarpPLS 6.o application. The result of this research indicates that the ROE and DAR have positive significant on Income smoothing. Meanwhile, CR has no signifanct on Income smoothing. This research also shows that Effective Tax Rate can mediate ROE toward Income Smoothing and Effective Tax Rate cannot mediate DAR and CR toward Income Smoothing.
\end{abstract}

Keywords: income smoothing; return on equity; debt to total asset; current ratio; efective tax rate

JEL Classification: $G_{30}$; $\mathrm{O}_{16}$

\footnotetext{
* Penulis koresponden

E-mail: teddyharyadi91@gmail.com
} 


\section{PENDAHULUAN}

Laporan keuangan bertujuan untuk menyediakan informasi yang menyangkut posisi keuangan, kinerja serta perubahan posisi keuangan suatu perusahaan yang bermanfaat bagi sejumlah besar pengguna dan pengambil keputusan. Laporan keuangan juga merupakan sarana informasi pertanggungjawaban manajemen atas penggunaan sumber daya yang dipercayakan kepada mereka.

Informasi laba pada Laporan Keuangan merupakan informasi yang penting dalam laporan keuangan bagi pihak manajemen yang mengakibatkan manajemen cenderung melakukan disfunctional behavior, yaitu suatu tindakan memaksimalkan laba dengan memanfaatkan fleksibilitas standar akuntansi yang digunakan oleh perusahaan. Disfunctional behavior timbul akibat adanya informasi asimetris antara pihak-pihak yang berkepentingan atau teori keganenan. Akibatnya, perusahaan termotivasi untuk melakukan manajemen laba (earnings management).

Income smoothing pada umumnya dilakukan oleh perusahaan untuk melihatkan kemampuan perusahaan kepada investor atau pun calon investor bahwa perusahaan tersebut dalam keadaan yang stabil dalam menghasilkan laba guna peningkatan nilai saham dan pemberian deviden. Sehingga investor yang lama tidak menarik investasinya diperusahaan tersebut dan investor yang baru tertarik untuk menanamkan uangnya di perusahaan tersebut.

Terdapat banyak faktor yang mempengaruhi perusahaan melakukan Income smoothing. Investor pada umumnya sebelum melakukan investasi pada suatu perusahaan melakukan penelaah laporan keuangan yang diterbitkan oleh perusahaan. Dan rasio keuangan merupakan salah satu hal yang sering dilihat oleh investor sebelum melakukan investasi. Sehingga Rasio keuangan sangat mempengaruhi investor dalam pengambilan keputusan untuk melakukan investasi.

Rasio keuangan merupakan salah satu cara yang digunakan untuk menganalisis laporan keuangan dalam melihat kinerja suatu perusahaan. Return on Equity (ROE) mencerminkan seberapa besar laba bersih yang diperoleh dari total ekuitas suatu perusahaan. Secara umum, Perusahaan yang memiliki ROE yang lebih rendah mempunyai kecenderungan untuk melakukan praktik perataan laba dari pada perusahaan yang memiliki ROE yang lebih tinggi. Hal ini dikarenakan perusahaan yang profitabilitasnya rendah akan dituntut untuk melakukan pengelolaan laba perusahaan agar para investor yang sudah menanamkan modalnya tidak berpindah haluan pada perusahaan lain. Sehingga hal tersebut dapat mempengaruhi manajemen untuk membuat tampilan laba menjadi lebih stabil dengan melakukan Income smoothing.

Debt To Total Assets (DAR) mencerminkan seberapa besar utang yang digunakan untuk membiayai total aset. Nilai DAR yang tinggi menggambarkan bahwa sebagian besar aset perusahaan dibiayai oleh utang. Sehingga DAR yang tinggi sering mendorong pihak manajement untuk melakukan perataan laba.

Current Ratio (CR) merupakan rasio yang digunakan untuk mengukur kemampuan perusahaan dalam memenuhi kewajiban lancarnya dengan total aset lancar yang dimiliki perusahaan. Nilai Current Ratio yang rendah suatu perusahaan mengalami kesulitan keuangan, maka perusahaan tersebut akan sulit membayar kewajiban jangka pendek maupun kewajiban jangka panjang yang telah jatuh tempo yang mengakibatkan perusahaan tersebut mencari dana dari pihak eksternal, seperti pihak investor maupun bank.

Menurut Richardson dan Lanis (2007) Tarif pajak efektif adalah perbandingan antara pajak riil yang kita bayar dengan laba komersial. Dan tarif pajak efektif ini juga bermanfaat bagi perusahaan untuk mengetahui sampai sejauh mana perusahaan tersebut dalam memanajemen sistem perpajakan yang berlaku. Karena apabila perusahaan memiliki persentase tarif pajak efektif yang lebih tinggi dari tarif yang 
ditetapkan maka perusaan kurang maksimal dalam memaksimalkan insentif-insentif perpajakan yang ada karena dengan perusahaan memanfaatkan insentif perpajakan yang ada maka dapat memperkecil persentase pembayaran pajak dari laba komersial.

Sehingga dari Dengan adanya manajement pajak yang dilakukan oleh perusahaan dapat memediasi hubungan ROE, DAR, dan CR terhadap Income Smooting

\section{TINJAUAN PUSTAKA}

\section{Teori Sinyal (Signalling Theory)}

Teori sinyal ini berkaitan dengan adanya asimetri informasi yang terjadi dimana salah satu pihak memiliki lebih banyak informasi yang bersifat privat dan penting mengenai keadaan perusahaan. Gonedes dalam Narsa dkk (2003) mengemukakan bahwa angka-angka akuntansi yang dilaporkan oleh pihak manajemen dapat digunakan sebagai sinyal bahwa angka-angka tersebut dapat mencerminkan informasi mengenai atribut-atribut keputusan perusahaan yang tidak terpantau. Asimetri informasi terjadi di pasar modal bila manajemen tidak menyampaikan semua informasi yang dimiliki secara penuh. Dalam hal ini informasi yang tidak disampaikan tersebut dapat mempengaruhi nilai pasar saham perusahaan tersebut, karena pasar akan merespon informasi yang dimiliki sebagai sinyal, maka nilai saham yang diperdagangkan dapat overvalued atau undervalued.

\section{Teori Akuntansi Positif (Positive Accounting Theory)}

Pada awal perkembangannya, teori akuntansi menghasilkan teori normatif yang didefinisikan sebagai teori yang mengharuskan dan menggunakan kebijakan nilai (value judgement) yang mengandung minimum sebuah premis. Teori normatif pada awalnya belum menggunakan pendekatan investigasi formal, baru pada perkembangan berikutnya mulai digunakannya pendekatan investigasi terstruktur formal, yaitu pendekatan deduktif (dimulai dari proposisi akuntansi dasar sampai dengan dihasilkan prinsip akuntansi yang rasional sebagai dasar untuk mengembangkan teknik-teknik akuntansi.

\section{Teori Agensi (Agency Theory)}

Teori keagenan mengasumsikan bahwa individu bertindak atas kepentingan mereka sendiri dan agen (manajer perusahaan) diasumsikan menerima kepuasan bukan saja dari kompensasi keuangan tetapi juga dari syarat-syarat yang terlibat dalam hubungan keagenan, seperti jumlah waktu luang, kondisi kerja yang menarik, keanggotaan klub dan jam kerja yang fleksibel.

Jensen dan Meckling (1976), menyatakan bahwa teori keagenan mendeskripsikan pemegang saham sebagai prinsipal dan manajemen sebagai agen. Manajemen merupakan pihak yang dikontrak oleh pemegang saham untuk bekerja demi kepentingan pemegang saham. Untuk itu manajemen diberikan sebagian kekuasaan untuk membuat keputusan bagi kepentingan terbaik pemegang saham. Oleh karena itu, manajemen wajib mempertanggung jawabkan semua upayanya kepada pemegang saham.

\section{Perataan Laba}

Perataan laba (Income smoothing) merupakan salah satu bentuk perilaku manajemen laba. Perataan laba diartikan sebagai usaha manajemen untuk mengurangi variabilitas laba selama satu atau beberapa periode tertentu sehingga 
laba tidak terlalu berfluktuasi. Praktik perataan laba ini dapat dianggap sebagai pemberian sinyal kepada pasar.

Definisi terbaik tentang perataan income yang diberikan oleh Belkaoui (2001) adalah upaya yang sengaja dilakukan untuk memperkecil atau fluktuasi pada tingkat laba yang dianggap normal bagi suatu perusahaan. Dalam pengertian ini perataan merepresentasi suatu bagian upaya manajemen perusahaan untuk mengurangi variasi tidak normal dalam laba pada tingkat yang diijinkan oleh prinsip-prinsip akuntansi dan manajemen yang sehat.

\section{Tarif Pajak Efektif}

Tarif Pajak Efektif adalah besarnya tarif riil yang dibayar oleh perusahaan. Richardson dan Lanis (2007) mendefinisikan tarif pajak efektif sebagai beban pajak penghasilan dibagi oleh pendapatan sebelum pajak.

Tarif pajak efektif yang tinggi diakibatkan pada saat koreksi fiskal terdapat banyak terjadi koriksi fiskal positif sehingga mengakibatkan laba fiskal yang tinggi. sedangkan tarif pajak efektif yang rendah diakibatkan pada saat koreksi fiskal banyak terdapat koreksi fiskal negatif sehingga mengakibatkan laba fiskal yang semakin rendah.

\section{Return on Equity (ROE)}

ROE atau Keberhasilan kinerja keuangan menunjukkan kemampuan perusahaan dalam menghasilkan laba dengan menggunakan modal sendirinya sehingga besarnya ROE mengindikasikan tingkat efisiensi perusahaan dalam mengelola modal sendirinya untuk menghasilkan keuntungan.

\section{Debt to Total Asset (DAR)}

DAR merupakan rasio antara total hutang (total debts) baik hutang jangka pendek (current liability) dan hutang jangka panjang (long term debt) terhadap total aktiva (total assets) baik aktiva lancar (current assets) maupun aktiva tetap (fixed assets) dan aktiva lainnya (other assets). Rasio ini menunjukkan besarnya hutang yang digunakan untuk membiayai aktiva yang digunakan oleh perusahaan dalam rangka menjalankan aktivitas operasionalnya.

\section{Current Ratio (CR)}

Rasio Likuiditas (Liquidity Ratio) digunakan untuk mengukur kemampuan perusahaan untuk memenuhi kewajiban jangka pendeknya dengan sumber daya jangka pendek (atau lancar) yang tersedia untuk memenuhi kewajiban tersebut (Van Horne dan Wachowics, 2013).

\section{Hipotesis}

$\mathrm{H}_{1}$ : ROE berpengaruh terhadap praktik perataan laba (Income smoothing)

$\mathrm{H}_{2}$ : Debt To Total Assets (DAR) berpengaruh terhadap praktik perataan laba (Income smoothing)

$\mathrm{H}_{3}$ : Current Ratio berpengaruh terhadap praktik perataan laba (Income smoothing)

$\mathrm{H}_{4}$ : ROE berpengaruh positif terhadap Effective Tax Rate (ETR)

$\mathrm{H}_{5}$ : Debt To Total Assets (DAR) berpengaruh negatif terhadap Effective Tax Rate (ETR)

$\mathrm{H}_{6}$ : Current Ratio (CR) berpengaruh terhadap Effective Tax Rate (ETR)

$\mathrm{H}_{7}$ : Effective Tax Rate (ETR) berpengaruh terhadap praktik perataan laba (Income smoothing)

$\mathrm{H}_{8}$ : Effective Tax Rate (ETR) Memediasi Pengaruh ROE terhadap praktik perataan laba (Income smoothing) 
$\mathrm{H}_{10}$ : Effective Tax Rate (ETR) Memediasi Pengaruh Current Ratio terhadap praktik perataan laba (Income smoothing)

\section{METODOLOGI PENELITIAN}

\section{Populasi dan Sampel}

Populasi dalam penelitian ini adalah perusahaan property dan real estate yang terdaftar di Bursa Efek Indonesia antara tahun 2013 sampai 2017. Sampel pada penelitian ini diambil dengan metode purposive sampling, yaitu penentuan sampel atas dasar kesesuaian karakteristik dan kriteria tertentu. Kriteria pemilihan sampel pada penelitian ini adalah sebagai berikut: a) Perusahaan mengalami laba berturutturut selama periode penelitian. b) Perusahaan property dan real estate yang terdaftar di Bursa Efek Indonesia (BEI) selama periode 2013 sampai 2017. c) Perusahaan yang menyajikan laporan tahunannya dalam website perusahaan atau website Bursa Efek Indonesia selama periode 2013-2017. d) Laporan keuangan perusahaan memiliki data-data yang berkaitan dengan variabel penelitian. e) Perusahaan yang melaporkan laporan keuangan dalam mata uang rupiah $(\mathrm{Rp})$ agar tidak terpengaruh oleh fluktuasi nilai rupiah terhadap dolar.

\section{Definisi Operasional dan Pengukuran Variabel}

\section{Variabel Endogen}

Nilai Income smoothing dihitung dengan menggunakan indeks Eckel (1981). Indeks Eckel menggunakan Coefficient Variation (CV) variabel laba dan penjualan bersih yang dapat dihitung dengan rumus sebagai berikut:

$$
\text { Indeks Income smoothing }=\frac{\mathrm{CV} \Delta \mathrm{I}}{\mathrm{CV} \Delta \mathrm{S}}
$$

Dimana:

$\Delta \mathrm{l}:$ Perubahan laba dalam satu periode

$\Delta S$ : Perubahan Penjualan dalam satu periode

CV : Koefisien variasi dari variabel yaitu standar deviasi dibagi dengan nilai yang diharapkan

Apabila CV $\Delta \mathrm{I}>\mathrm{CV} \Delta \mathrm{S}$, maka perusahaan tidak digolongkan melakukan Income smoothing; sebaliknya bila $\mathrm{CV} \Delta \mathrm{I}<\mathrm{CV} \Delta \mathrm{S}$, maka perusahaan digolongkan melakukan Income smoothing.

\section{Variabel Intervening (Mediasi)}

\section{Tarif Pajak Efektif}

Richardson dan Lanis (2007) mendefinisikan Tarif Pajak Efektif perbandingan antara pajak yang dibayar pada tahun tersebut dengan laba sebelum pajak.

Tarif Pajak Efektif dihitung dengan menggunakan rumus:

$$
\text { Tarif Pajak Efektif }=\frac{\text { Pajak kini }}{\text { Laba sebelum pajak }(E B T)} \times 100 \%
$$

\section{Variabel Eksogen}

Return on Equity (ROE) 
Profitabilitas perusahaan diukur dengan menggunakan rasio $\mathrm{ROE}$, yaitu rasio yang menunjukkan berapa persen diperoleh laba bersih bila diukur dari modal pemilik. Skala pengukurannya skala rasio dengan rumus:

$$
\text { Return on Equity }=\frac{\text { Net Income After Tax }}{\text { Total Equity }}
$$

Leverage perusahaan diukur dengan menggunakan rasio Debt To Total Assets (DAR), yaitu rasio yang menghitung berapa banyak dari total aset perusahaan yang dibiayai dengan menggunakan total utang/dana pinjaman.

\section{Current Ratio (CR)}

Menurut Weston dan Copeland (1997) Current Ratio merupakan rasio yang digunakan untuk mengukur besarnya kewajiban lancar yang dilunasi dengan aset lancar. Adapun Current Ratio dihitung dengan membagi aset lancar dengan kewajiban lancar seperti rumus sebagai berikut:

$$
\text { Current Ratio }=\frac{\text { Current Asset }}{\text { Curren Liabilities }}
$$

\section{Metode Analisis Data}

\section{Analisis Partial Least Square (PLS)}

Pada penelitian ini untuk mengetahui pengaruh antara variabel dilakukan dengan pendekatan Structural Equation Model (SEM) dengan menggunakan software Partial Least Square (PLS) yaitu software warpPLS versi 6.0. PLS merupakan metoda SEM berbasis varian yang didesain untuk menyelesaikan persoalan yang tidak dapat dilakukan oleh CB-SEM seperti jumlah sampel kecil, data tidak berdistribusi normal secara multivariate, adanya missing values, dan adanya problem multikolinieritas antar variable eksogen (Ghozali dan Latan, 2012).

Ghozali dan Latan (2012) menyatakan bahwa model evaluasi PLS dilakukan dengan menilai outer model dan inner model. Evaluasi model pengukuran atau outer model pada data yang memiliki indikator formatif dilakukan dengan mengevaluasi indicator weigth. Sholihin dan Ratmono (2013) menyatakan bahwa untuk mengevaluasi kelayakan pengukuran indicator formatif adalah dengan menggunakan dua kriteria: 1) Bobot indikator (indicator weight) harus signifikan secara statistis. 2) Multikolinieritas atau nilai VIF (Variance Infation Factor) harus lebih kecil dari 3,3.

$$
\begin{aligned}
& \eta 1=\gamma 1 \xi 1+\gamma 2 \xi 2+\gamma 3 \xi 3+\zeta 1 \\
& \eta 2=\beta 1 \eta 1+\gamma 1 \xi 1+\gamma 2 \xi 2+\gamma 3 \xi 3+\zeta 2
\end{aligned}
$$

Dimana $\eta$ adalah variabel endogen yang terdiri dari $\eta 1$ (Income smoothing),

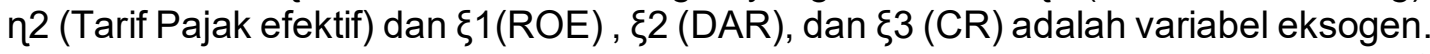
$Y$ adalah koefisien jalur yang menghubungkan predictor eksogen dengan endogen. $\beta$ adalah koefisien jalur yang menghubungkan predictor endogen dengan endogen sedangkan $\zeta$ adalah inner residual variable.

\section{HASIL PENELITIAN DAN PEMBAHASAN}

\section{Hasil Evaluasi Model Pengukuran (outer model)}

Dalam menguji outer model untuk data yang bersifat observe data dijadikan sebagai indikator formatif. Dalam mengevaluasi indikator formatif dilakukan dengan 
melihat indikator weight. Hasil evaluasi outer model pada indikator yang bersifat formatif dapat dilihat pada Tabel 1.

Tabel 1. Hasil Pengujian Indicator Weigth

\begin{tabular}{lcccccccc}
\hline & IS & TPE & ROE & DAR & CR & Type & VALUE & VIF \\
\hline IS & -1.000 & 0.000 & 0.000 & 0.000 & 0.000 & Formatif & $<0.001$ & 0.000 \\
\hline TPE & 0.000 & -1.000 & 0.000 & 0.000 & 0.000 & Formatif & $<0.001$ & 0.000 \\
\hline ROE & 0.000 & 0.000 & -1.000 & 0.000 & 0.000 & Formatif & $<0.001$ & 0.000 \\
\hline DAR & 0.000 & 0.000 & 0.000 & -1.000 & 0.000 & Formatif & $<0.001$ & 0.000 \\
\hline CR & 0.000 & 0.000 & 0.000 & 0.000 & -1.000 & Formatif & $<0.001$ & 0.000 \\
\hline
\end{tabular}

Sumber: Hasil Olahan WarpPLS 6.0

Pada Tabel 1 dapat dilihat bahwa tidak ada terdapat indicator variable yang memiliki nilai VIF di atas 3,3 dan nilai $P$ value $<0,05$ untuk semua indicator. Sehingga dapat disimpulkan bahwa data formatif pada penelitian telah layak untuk diuji.

\section{Hasil evaluasi model Struktural atau Inner Model}

\section{Koefisien Determinasi}

Tabel 2. Hasil Pengujian R-Squared

\begin{tabular}{cc}
\hline Variable Laten & R-Squared \\
\hline Tarif Pajak Efektif & 0,17 \\
\hline Income smoothing & 0,15 \\
\hline
\end{tabular}

Sumber: Hasil Olahan WarpPLS 6.0

Tabel 2 menunjukkan bahwa variable Tarif Pajak Efektif dapat dijelaskan oleh variabel ROE, DAR, Current Ratio (CR) hanya sebesar 0,17 atau $17 \%$ sedangkan sisanya $83 \%$ dijelaskan oleh variabel lain diluar model penelitian. Hal ini berarti Pengaruh Rasio keuangan yang diteliti terhadap Tarif Pajak efektif adalah pengaruh lemah karena nilai R-Square dibawah 25\%.Selanjutnya Variabel Income smoothing dapat dijelaskan oleh variabel ROE, DAR, CR dan Tarif pajak Efektif hanya sebesar 0,15 atau $15 \%$. Sedangkan sisanya $85 \%$ dijelaskan oleh variabel lain diluar model penelitian. Hal ini berarti Pengaruh ROE, DAR, CR dan Tarif pajak Efektif terhadap Income smoothing adalah pengaruh lemah karena nilai $R$-Square dibawah $25 \%$.

\section{Model Fit Index}

Untuk mengevaluasi Model Fit dapat ditentukan oleh beberapa indikator fit yang hasilnya dapat dilihat pada Gambar 1. Pada Gambar 1 dapat dilihat bahwa nilai average path coefficient (APC) sebesar 0,241 dengan p-value $=0,012$, Average $R$ Squared (ARS) sebesar $0.159 \mathrm{p}$-value $=0,049$, Average Adjusted $R$-Squared (AARS) sebesar $0.106 p$-value $=0,099$. Untuk nilai AARS memiliki nilai $p$-value diatas 0,05. Artinya model pada penelitian ini tidak memenuhi model fit index.

Kemudian nilai Average Block Variance Inflation Factor (AVIF) sebesar 1,209 dan Average full collinearity VIF (AFVIF) sebesar 1,336 <3,3. Ini dapat diartikan bahwa tidak ada masalah multikolonieritas antar indicator dan antar variable eksogen. Selanjutnya nilai Tenenhaus Goodness of Fit (GoF) sebesar 0,399 > 0,36.

Ghozali dan Latan (2015) menyebutkan bahwa interpretasi dari model fit diatas tergantung dari tujuan analisis SEM. Jika tujuan hanya untuk menguji hipotesis, 
maka setiap jalur mempresentasikan hipotesis, maka evaluasi fit model kurang begitu penting. Namun sebaliknya, jika tujuan analisisnya adalah untuk menemukan suatu model yang fit dengan data orisinalnya, maka evaluasi model fit menjadi penting dan bermanfaat untuk mengukur kualitas model.

\section{Model fit and quality indices}

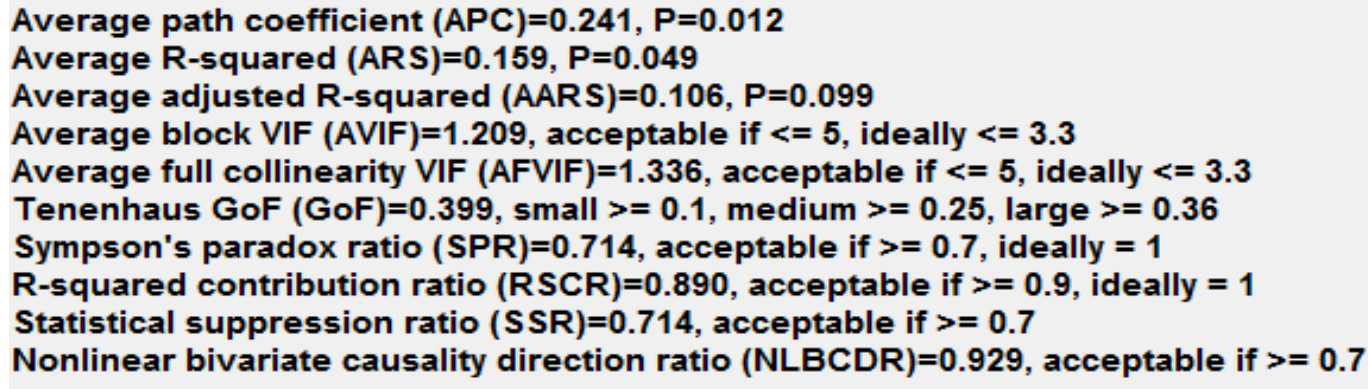

Sumber: Hasil Olahan WarpPLS 6.0

Gambar 1. Hasil Pengujian Model Fit Index

\section{Hasil Pengujian Hipotesis}

Berikut ini merupakan hasil evaluasi model struktural pengaruh langsung variabel eksogen terhadap variabel endogen.

Tabel 3. Hasil Uji Hipotesis Pengaruh Langsung

\begin{tabular}{lllll}
\hline \multirow{2}{*}{ No. } & \multicolumn{1}{c}{ Jalur } & \multicolumn{2}{c}{ Direct Effect } & \multirow{2}{*}{ Keterangan } \\
\cline { 3 - 4 } & & Koef & p-Value & \\
\hline H1 & ROE $\rightarrow$ INCOME SMOOTHING & 0,26 & 0,02 & Signifikan $(+)$ \\
H2 & $\begin{array}{l}\text { DEBT TO TOTAL ASSETS (DAR) } \rightarrow \\
\text { INCOME SMOOTHING }\end{array}$ & 0,28 & $<0,01$ & Signifikan $(+)$ \\
H3 & $\begin{array}{l}\text { CURRENT RATIO (CR) } \rightarrow \text { INCOME } \\
\text { SMOOTHING }\end{array}$ & 0,15 & 0,12 & Tidak Signifikan \\
H4 & ROE $\rightarrow$ TARIF PAJAK EFEKTIF & $-0,41$ & 0,01 & Signifikan $(+)$ \\
H5 & $\begin{array}{l}\text { DEBT TO TOTAL ASSETS (DAR) } \rightarrow \\
\text { TARIF PAJAK EFEKTIF }\end{array}$ & $-0,16$ & 0,1 & Tidak Signifikan \\
H6 & $\begin{array}{l}\text { CURRENT RATIO (CR) } \rightarrow \text { TARIF PAJAK } \\
\text { EFEKTIF }\end{array}$ & $-0,17$ & 0,08 & Tidak Signifikan \\
H7 & $\begin{array}{l}\text { TARIF PAJAK EFEKTIF } \rightarrow \text { INCOME } \\
\text { SMOOTHING }\end{array}$ & 0,26 & 0,02 & Signifikan $(+)$ \\
\hline
\end{tabular}

Sumber : Hasil Olahan WarpPLS 6.0

Secara statistik signifikan pada level alpha 5\% ( $\alpha: 0,05)$

\section{Pengaruh ROE Terhadap Income smoothing}

Tabel 3 menunjukkan bahwa ROE berpengaruh terhadap Income smoothing. hal ini dapat dilihat dari koefisien jalur sebesar 0,26 dan memiliki nilai signifikan sebesar $0,02<0.05$. 
Hal ini dikarenakan pihak manajemen ingin memperlihatkan kepada stakeholder dan shareholder bahwa laba yang dihasilkan oleh perusahaan tersebut akan selalu stabil. Sehingga perusahaan yang memiliki Return on Equity yang tinggi cenderung melakukan praktek Income smoothing. Hasil penelitian ini sejalan dengan hasil penelitian yang dilakukan oleh Mendila (2013), Widana dan Yasa (2013) dan Lubis (2012) Namun hasil ini berlawanan dengan Li-Jung dan Chien-Wen (2007) yang tidak memiliki pengaruh terhadap Income smoothing.

\section{Pengaruh Debt To Total Assets (DAR) Terhadap Income smoothing}

Tabel 3 menunjukkan bahwa Debt To Total Assets (DAR) berpengaruh positif terhadap Income smoothing. hal ini dapat dilihat dari koefisien jalur sebesar 0.28 dan memiliki signifikan sebesar 0,01<0,05.

$\mathrm{Hal}$ ini diakibatkan perusahaan yang memiliki DAR yang tinggi cenderung melakukan praktik Income smoothing karena perusahaan terancam default, yaitu tidak dapat memenuhi kewajiban pembayaran hutang pada waktunya. Hal ini dilakukan untuk mendapatkan posisi bargaining yang relatif baik dalam negoisasi atau penjadwalan ulang utang dari pihak kreditor. Hasil I ini sejalan dengan hasil penelitian Zuhroh (1996), Jin dan Machfoedz (1998) dan Assih dan Gudono (2000).

\section{Pengaruh Current Ratio (CR) Terhadap Income smoothing}

Tabel 3 menunjukkan bahwa Current Ratio (CR) tidak berpengaruh terhadap Income smoothing. hal ini dapat dilihat dari koefisien jalur sebesar 0.15 dan memiliki signifikan sebesar 0,12>0,05.

Pada penelitian ini membuktikan bahwa CR tidak berpengaruh terhadap dilakukannya Income smoothing. Hal ini menunjukkan bahwa manajer dalam melakukan Income smoothing tidak memperhatikan tinggi rendahnya likuiditas perusahaan dan hanya terfokus pada kestabilan laba yang diperoleh oleh perusahanan $\mathrm{Hal}$ ini bertentangan dengan hasil penelitian yang dilakukan oleh Vivian (2015). Namun, sejalan dengan penelitian Pratnatika (2017), Irawan dkk (2016), dan Banam dan Mehrazeen (2016).

\section{Pengaruh ROE Terhadap Tarif Pajak Efektif}

Tabel 3 menunjukkan bahwa ROE berpengaruh terhadap Tarif Pajak Efektif. Hal ini dapat dilihat dari koefisien jalur sebesar -0.41 dan memiliki signifikan sebesar $0,01<0,05$.

Pada penelitian ini membuktikan bahwa Perusahaan dengan tingkat profitabilitas yang tinggi dapat membayar pajak lebih rencah dari perusahaan yang memiliki profitabilitas yang rendah. Penyebabnya adalah karena manajer berusaha untuk melakukan manajemen pajak dengan memanfaatkan fasilitas-fasilitas perpajakan yang ada sehingga dapat mengefisienkan pembayaran pajaknya sehingga perusahaan dapat membayar pajak lebih sedikit. Hasil ini sejalan dengan hasil penelitian Alexandru dan Georgeta (2013) serta Andreea dan Georgeta (2013).

\section{Pengaruh Debt To Total Assets (DAR) Terhadap Tarif Pajak Efektif}

Tabel 3 menunjukkan bahwa Debt To Total Assets (DAR) tidak berpengaruh terhadap Tarif Pajak Efektif. Hal ini dapat dilihat dari koefisien jalur sebesar -0.16 dan memiliki signifikan sebesar 0,10>0,05. penetilan ini menunjukkan bahwa pihak manajemen tidak menggunakan biaya bunga yang timbul pada hutang dalam melakukan manajemen perpajakannya. Hal ini dikarenakan beban bunga yang besar 
dapat memakan laba perusahaan sehingga membuat manajer perusahaan menghindari hutang dalam melakukan manajemen perpajakannya guna memaksimalkan laba perusahaan. Hasil isi mendukung hasil penelitian yang dilakukan oleh Ardyansyah dan Zulaikha (2014) dan Nimatur (2015).

\section{Pengaruh Current Ratio (CR) Terhadap Tarif Pajak Efektif}

Tabel 3 menunjukkan bahwa CR tidak berpengaruh terhadap Tarif Pajak Efektif. Hal ini dapat dilihat dari koefisien jalur sebesar -0.17 dan memiliki signifikan sebesar $0,08>0,05$. Hal ini menunjukkan likuiditas perusahaan tidak mempengaruhi besarnya pembayaran pajak kepada Negara. Hal ini karena perusahaan objek dalam penelitian tidak memfokuskan pada rasio keuangan dalam melakukan mengelola pajaknya sehingga dalam penelitian ini mendapatkan bahwa CR tidak berpengaruh terhadap Tarif Pajak Efektif. Hasil penelitian ini sesuai dengan penelitian Tiaras dan Wijaya (2015) dan Suyanto dan Supramono (2012) bahwa tidak ada pengaruh antara likuiditas perusahaan terhadap Effective Tax Rate (ETR).

\section{Pengaruh Tarif Pajak Efektif Terhadap Income smoothing}

Tabel 3 menunjukkan Tarif Pajak Efektif berpengaruh terhadap Income smoothing. Hal ini dapat dilihat dari koefisien jalur sebesar 0.26 dan memiliki signifikan sebesar $0,02<0,05$. Hal ini dikarenakan bahwa manajer ingin membayar pajak seminimal mungkin. Keinginan manajemen untuk selalu membayar pajak yang rendah merupakan salah satu faktor yang mendorong pihak manajemen untuk melakukan praktik Income smoothing. Hasil ini sejalan dengan Kusumawati (2002) dan Widiawati (2016).

\section{Pengujian Signifikansi Pengaruh Tidak Langsung}

Menurut Ghozali dan Latan (2012) salah satu syarat pengujian hipotesis mediasi adalah ketiga jalur harus signifikan yaitu variabel Eksogen $\rightarrow$ Endogen, Eksogen $\rightarrow$ Pemediasi dan Pemediasi $\rightarrow$ Endogen. Dalam pengujian hipotesis mediasi menggunakan metode yang dikembangkan oleh Baron den Kenny yang mana syarat pengujian mediasi harus signifikan pada ketiga jalur.

\section{Pengaruh ROE Terhadap Income smoothing Dimediasi Oleh Tarif Pajak Efektif}

Tabel 3 menunjukkan bahwa Tarif Pajak Efektif mampu memediasi pengaruh ROE Terhadap Income smoothing. Hal ini diketahui bahwa semua jalur yang signifikan pada pengaruh ROE terhadap Tarif Pajak Efektif dengan nilai $p=0,01<$ 0,05 dan pengaruh Tarif Pajak Efektif terhadap Income smoothing $p=0,02<0,05$. Dari hasil pengujian terebut dapat disimpulkan bahwa Tarif Pajak Efektif memediasi hubungan ROE Terhadap Income smoothing.

\section{Pengaruh Debt To Total Assets (DAR) Terhadap Income smoothing Dimediasi Oleh Tarif Pajak Efektif}

Tabel 3 menunjukkan bahwa Tarif Pajak Efektif tidak mampu memediasi pengaruh DAR Terhadap Income smoothing. Hal ini diketahui bahwa terdapat satu nilai koefisien jalur yang tidak signifikan DAR terhadap Tarif Pajak Efektif dengan nilai $p=0,10>0,05$. Dari hasil pengujian tersebut dapat disimpulkan Tarif Pajak Efektif tidak memediasi hubungan DAR Terhadap Income smoothing. 


\section{Pengaruh Current Ratio (CR) Terhadap Income smoothing Dimediasi Oleh Tarif Pajak Efektif}

Tabel 3 menunjukkan bahwa Tarif Pajak Efektif tidak mampu memediasi pengaruh CR Terhadap Income smoothing. Hal ini diketahui bahwa terdapat satu nilai koefisien jalur yang tidak signifikan CR terhadap Tarif Pajak Efektif dengan nilai $p=$ $0,08>0,05$. Dari hasil pengujian tersebut dapat disimpulkan Tarif Pajak Efektif tidak memediasi hubungan CR Terhadap Income smoothing.

\section{KESIMPULAN}

Berdasarkan hasil analisis dan pembahasan yang telah dijelaskan di bab sebelumnya, maka dapat diambil kesimpulan bahwa ROE, DAR berpengaruh terhadap Income smoothing sedangkan CR tidak berpengaruh terhadap Income smoothing. Penelitian ini juga menunjukkan Tarif Pajak Efektif dapat memediasi hubungan ROE terhadap Income smoothing dan Tarif Pajak Efektif tidak dapat memediasi hubungan DAR, dan CR terhadap Income smoothing.

Berdasarkan hasil dari penelitian ini dapat dikemukakan saran untuk penelitian selanjutnya adalah disarankan untuk penelitian selanjutnya dapat melakukan pada sektor lainnya seperti manufaktur dan pertambangan agar mendapatkan prediksi perilaku Income smoothing yang dilakukan oleh pihak manajemen dalam suatu sektor perusahaan. Dan menambahkan rasio keuangan yang lain seperti intensitas persedian, ROA, dan ukuran perusahaan sebagai variabel eksogen.

\section{DAFTAR PUSTAKA}

Alexandru, I., dan V. Georgeta. 2013. Analysis of the determinant factors of the effective tax rate. Academy of Economic Studies. MASTER DAFI Financial Management and Stock Exchange - ASE Bucharest, 7:1-12.

Andreea dan V. Georgeta. 2013. The Analysis of Correlation between Profit Tax and Corporate Financial Performance. Academy of Economic MASTER $D A F I$ - Financial Management and Stock Exchange - ASE Bucharest, 6: 112.

Ardyansyah, D., dan Zulaikha. 2014. Pengaruh Size, Leverage, Profitability, Capital Intensity Ratio Dan Komisaris Independen Terhadap Effective Tax Rate (Etr). Semarang: Fakultas Ekonomika dan Bisnis Universitas Diponegoro.

Assih, P., dan M. Gudono. 2000. Hubungan Tindakan Perataan Laba dengan Reaksi Pasar atas Pengumuman Informasi Laba Perusahaan yang Terdaftar di Bursa Efek Jakarta. Jurnal Riset Akuntansi Indonesia, 3(1): pp 35-53.

Banam, M., and A. Mehrazeen. 2016. The Relationship Of Information Asymmetry, Institutional Ownership aand Stock Liquidity With Income Smoothing in Tehran Stock Exchange. UCT Journal of Management and Accounting Studies, 4(3): 10-15.

Belkaoui, A.R. 2001. Teori Akuntansi. Alih Bahasa Mawinta, Hajayanti Widiastuti, Heri Kurniawan, Alia Arisanti. Jakarta: Penerbit Salemba Empat.

Eckel, N. 1981. The Income Smoothing Hypothesis Revisited. Abacu 17(1): 28-40. https://doi.org/10.1111/j.1467-6281.1981.tb00099.x 
Ghozali, I., dan H. Latan. 2015. Konsep, Teknik, Aplikasi Menggunakan Smart PLS 3.0 Untuk Penelitian Empiris. Semarang: BP Undip.

Irawan, T., S. Ruwanti, dan T. Manik. 2016. Analisis Pengaruh Ukuran Perusahaan, Leverage, Profitabilitas dan Likuiditas Terhadap Perataan Laba Pada Perusahaan Sektor Industri Dasar dan Kimia yang Terdaftar di Bursa Efek Indonesia Periode 2011-2014. Skripsi. Universitas Maritim Raja Ali Haji.

Jensen dan Meckling. 1976. Pengaruh Kepemilikan Manajerial, Kepemilikan Institusional, Dividen, Pertumbuhan Perusahaan, Free Cash Flow dan Profitabilitas Terhadap Kebijakan Hutang Perusahaan. Jurnal Bisnis dan Akuntansi, 11(3): 189-207.

Jin, L.S., dan M. Machfoedz. 1998. Faktor-faktor yang Mempengaruhi Praktik Perataan Laba pada Perusahaan yang Terdaftar di Bursa Efek Jakarta. Jurnal Riset Akuntansi Indonesia, 1(2): 174-191.

Kusumawati, H. 2002. Faktor-Faktor yang Mempengaruhi Praktek Perataan Laba pada Perusahaan Perbankan Non Go Public di Indonesia (Tahun 19952000). Tesis. Program Studi Magister Manajemen, Program Pasca Sarjana Universitas Diponegoro.

Li-Jung, T., dan L. Chien-Wen. 2007. Relationship Between Income Smoothing and Company Profitability: An Empirical Study. International Journal of Management, 24(4): 727-733.

Lubis, N.S. 2012. Pengaruh Return On Investment (ROI), Return on Equity (ROE), Leverage Operasi Terhadap Indikasi Perataan Laba (Income Smoothing) Pada Perusahaan Manufaktur Di Bursa Efek Indonesia (BEI). Skripsi. Sekolah Tinggi Ilmu Ekonomi Indonesia (STIESIA) Surabaya.

Mendila, Z. 2013. Praktik Perataan Laba Pada Perusahaan Perdagangan, Jasa, dan Investasi yang Terdaftar di Bursa Efek Indonesia. Skripsi. Universitas Bina Nusantara.

Narsa, I.M., B.D. Nugraheni, dan B. Maritza. 2003. Faktorfaktor yang Mempengaruhi Praktik Perataan Laba selama Krisis Moneter pada Perusahaan yang Terdaftar di Bursa Efek Surabaya. Majalah Ekonomi. Tahun XIII, No.2, Agustus.

Nimatur, R. 2015. Pengaruh Leverage Dan Capital Intensity Ratio Terhadap Effective Tax Rate: Dimoderasi Oleh Profitability (Studi Empiris Pada Perusahaan Manufaktur yang Terdaftar di BEI Tahun 2011-2013). Jom Fekon, 2(2): 1-13

Pratnatika, L.S. 2017. Pengaruh Ukuran Perusahaan, Return On Asset, Leverage Operasi, Likuiditas, Winner/Loser Stock Terhadap Praktik Perataan Laba. Skripsi. Universitas Muhammadiyah Yogyakarta.

Richardson, G., and B.R. Lanis. 2007. Determinants of the variability in corporatin offective tax rates and tax reform: Evidence from Australia. Journal of Accounting and Public Policy, 26: 689-704. https://doi.org/10.1016/j.jaccpubpol.2007.10.003

Sholihin, M., dan D. Ratmono. 2013. Analisis SEM-PLS dengan WarpPLS 3.0 untuk Hubungan Nonlinier Dalam Penelitian Sosial dan Bisnis. Yogyakarta: Penerbit Andi. 
Suyanto, K.D., dan Supramono. 2012. Likuiditas, leverage, komisris independen, dan manajemen laba terhadap agresivitas pajak perusahaan. Jurnal Keuangan dan Perbankan, 16: 167-177.

Tiaras, I., dan H. Wijaya. 2015. Pengaruh Likuiditas, Leverage, Manajemen Laba,Komisaris Independen dan Ukuran Perusahaan Terhadap Agresivitas Pajak. Jurnal Akuntansi, 19(3): 380-397. https://doi.org/10.24912/ja.v19i3.87

Van Horne, J.C., and J.M. Wachowics. 2013. Prinsip-Prinsip Manajemen Keuangan. Jakarta: Salemba Empat.

Vivian. 2015. Analisis Pengaruh Rasio Keuangan Terhadap Income Smoothing Dengan Ukuran Perusahaan Sebagai Variabel Moderating Pada Perusahaan Perkebunan Yang Terdaftar Di Bursa Efek Indonesia Dan Bursa Malaysia. Skripsi. Universitas Sumatera Utara

Weston, J.F., dan T.E. Copeland. 1997. Manajemen Pendanaan. Edisi 9. Jakarta: Bina Rupa Aksara.

Widana, I.N.A., dan G.W. Yasa. 2013. Perataan Laba Serta Faktor-Faktor Yang Mempengaruhinya di Bursa Efek Indonesia. E-Jurnal Akuntansi Universitas Udayana, 3(2): 297-317.

Widiawati, A. 2016. Analisa Pengaruh Faktor Profitabilitas, Kepemilikan Manajerial, Pajak, Financial Leverage, dan Ukuran Perusahaan terhadap Praktik Perataan Laba (income smoothing) pada Perusahaan Property dan Real Estate di BEI Tahun 2010-2014. Skripsi. Universitas Lampung.

Zuhroh, D. 1996. Faktor-Faktor yang Berpengaruh pada Tindakan Perataan Laba pada Perusahaan Go Public di Indonesia. Tesis. Program Pasca Sarjana Universitas Gadjah Mada. 